\title{
Acute Effects of Moderate and Strenuous Running on Trace Element Distribution in the Brain, Liver, and Spleen of Trained Rats
}

\author{
Kıvanç Ergen1, Hürrem Ince ${ }^{2}$, Halil Düzova ${ }^{3}$, Yunus Karakoç4, M. Hanifi Emre 3 \\ ${ }^{1}$ Department of Biophysics, Faculty of Medicine, Zonguldak Karaelmas University, Zonguldak, Turkey \\ 2Department of Chemistry, Faculty of Science and Literature, İstanbul Technical University, İstanbul, Turkey \\ ${ }^{3}$ Department of Physiology, Faculty of Medicine, Inönü University, Malatya, Turkey \\ ${ }^{4}$ Department of Biophysics, Faculty of Medicine, Inönü University, Malatya, Turkey
}

\section{ABSTRACT}

Objective: Trace elements such as manganese (Mn), cobalt (Co) and chromium (Cr) play key roles in metabolic reactions and are important in many physiological enzymatic processes. In this study, we aimed to investigate the acute effects of moderate and strenuous running (treadmill) exercise on the levels of $\mathrm{Mn}, \mathrm{Co}$ and $\mathrm{Cr}$ in the brain, liver, and spleen of trained rats.

Study Design: Animal experiment.

Material and Methods: Twenty-one Wistar-Albino adult male rats were used in the study. Rats were grouped as control group (no mandated exercise; $\mathrm{n}=8$ ), moderate exercise group (30 min exercise duration; $n=7)$, and strenuous exercise group ( 60 min exercise duration; $n=6)$. The levels of $\mathrm{Mn}, \mathrm{Co}$, and $\mathrm{Cr}$ in the frontal lobe, temporal lobe, brain stem, liver, and spleen were determined by atomic absorption spectrophotometer.

Results: $\mathrm{Cr}$ levels in liver of rats increased in parallel to the time course of running supporting the exercise training effect on the action of insulin. Compared to the control group, the level of Co significantly decreased in the brain stem of rats in the moderate exercise group ( $p=0.009$ ) and in the frontal lobe of rats in the strenuous exercise group ( $p=0.004)$. In the strenuous exercise group, an examination of the brain stem revealed that the level of Mn significantly decreased $(p=0.001)$, and levels of $\mathrm{Co}$ and $\mathrm{Cr}$ were apparently depleted to the extent that these elements were no longer detectable.

Conclusion: A notable finding is that during or after single bout strenuous exercise, levels of Co decreased in the spleen and particularly decreased in the brain stem of regularly trained rats. From this study, it can be inferred that sportsmen should aware trace element disturbances among the body parts or depletion of some trace elements after single bout of chronic strenuous running exercise.

Key Words: Manganese, cobalt, chromium, dietary supplements

Received: 15.03 .2012

\section{Introduction}

Trace elements such as manganese (Mn), cobalt (Co) and chromium ( $\mathrm{Cr}$ ) play key roles in metabolic reactions and are important in many physiological enzymatic processes. This is illustrated by the observation that the proper balance of trace element concentrations can be essential for proper metabolic functioning (1-3). Interestingly, specific regions of the brain have been shown to have unequal distributions of metabolic enzymes (4). Previously, unequal distributions were also shown for neurotransmitters (5). Moreover, it is not surprising that unequal distribution is also valid for trace elements (6-9). To examine the roles of trace elements and to study the physiological states that can lead to imbalances in trace element distribution and can thereby affect the brain and central nervous system, it is necessary to focus on the quantification of essential and toxic trace elements under conditions that are controlled for nutritional, biomedical and environmental variables. It is notable that aerobic exercise has been shown to alter the excretion and distribution of chromium (10). Further- more, it has also been reported that a single bout of strenuous exercise significantly increased the urinary output of $\mathrm{Cr}$ in male runners (11). This suggests the possibility that repeated strenuous exercise could lead to $\mathrm{Cr}$ depletion in some body systems (12). It has also been reported that exercised athletes have lower basal urinary $\mathrm{Cr}$ excretion, thus potentially preventing further $\mathrm{Cr}$ depletion with athletes (13).

Although some aspects of trace element biology have been studied relatively extensively, very little has been reported about physiological $\mathrm{Mn}$ concentrations and changes in $\mathrm{Mn}$ levels during sports and physical activities (9). Apart from this, the existing literature on the levels and functions of $\mathrm{Co}$ and $\mathrm{Cr}$ in the spleen is scarce. One additional gap in knowledge is that there are currently no known studies that examine the effect of running exercise on the metabolism of $\mathrm{Cr}, \mathrm{Mn}$ and $\mathrm{Co}$ in the brain. This is an area of study that is potentially very interesting, as trace elements have been shown to impact neural physiology and development (1-3). And it is possible that different exercise protocols could alter their concentrations in neuronal tissues just as exercise altered the $\mathrm{Cr}$ profile in the above study 
(11). From this perspective, such a study could have scientific import as well as practical application, since it may be helpful for athletes involved in vigorous training regimes to supplement their diets with certain trace elements if it is found that these elements are substantially decreased by strenuous exercise. To examine these issues, we used a rat model system to investigate the acute effects of moderate and strenuous running exercise on $\mathrm{Cr}, \mathrm{Mn}$ and $\mathrm{Co}$ metabolism in the liver and spleen as well as in several areas of the brain in regularly trained rats.

\section{Material and Methods}

\section{Animals}

Twenty-one Wistar-Albino adult male rats were used in the study, in accordance with $\mathrm{NIH}$-approved principles of laboratory animal care. The study protocol was approved by the Inonu University Ethics Committee for Experimental Animals. Rats in the control group (no mandated exercise; $n=8$ ), moderate exercise group (30 min exercise duration; $n=7$ ), and strenuous exercise group ( 60 min exercise duration; $n=6$ ) were housed in three groups in colony cages at an ambient temperature of $23^{\circ} \mathrm{C}$ with a $12 \mathrm{~h}$ light $/ 12 \mathrm{~h}$ dark cycle. The animals had free access to water and standard pellet chow containing $1.8-2.2 \%$ of calcium, $1.1 \%$ of phosphorus and $2650 \mathrm{kcal} / \mathrm{kg}$ energy.

\section{Exercise model}

The mandated exercise consisted of treadmill running, which was carried out essentially as in a previous study (14). A steep grade treadmill incline was used to stimulate high-intensity muscle activity in rats, and training consisted of treadmill running 5 days per week during a period of 13 weeks. Rats in the moderate and strenuous exercise groups began training when they were 63 days old and were successively adapted to the treadmill exercise by gradually increasing the exercise progression over the course of a week. During this period, running time was gradually increased from $15 \mathrm{~min}$ to $30 \mathrm{~min}$ (moderate) or to $60 \mathrm{~min}$ (strenuous) per session. Treadmill speed was similarly gradually increased to $45 \mathrm{~cm} / \mathrm{s}$, and the inclination was increased in increments of $2-3^{\circ}$ to reach a final grade of $18^{\circ}$ (Table 1, 2). Ten min after the last exercise training session, which took place 13 weeks after the initiation of the program, the rats were sacrificed and samples of tissue were collected and processed as indicated below.

\section{Sample preparation}

Tissue samples were weighed and then transferred into metal-free glass tubes for digestion, and were kept at $-84^{\circ} \mathrm{C}$ until use. For analysis, samples were prepared essentially as previously reported (15-17): Tissue samples were first digested with $2 \mathrm{~mL}$ concentrated nitric acid at $100^{\circ} \mathrm{C}$ for 1 hour and then cooled to room temperature, after which $2 \mathrm{~mL}$ of $60 \%$ perchloric acid (60\%) was added, and the samples were completely digested at $120^{\circ} \mathrm{C}$ until the volume was decreased by half. The digested materials were then diluted with deionized water to a final volume of $10 \mathrm{~mL}$ and agitated on a shaker for 15 minutes just before being measured for trace elements.

Table 1. Weekly variation in treadmill speed, inclination, and running time of moderate exercise group

\begin{tabular}{|c|c|c|c|c|c|c|c|c|c|}
\hline \multirow[b]{2}{*}{ Days } & & \multicolumn{7}{|c|}{ Weeks } & \multirow[b]{2}{*}{$8-13$} \\
\hline & & 1 & 2 & 3 & 4 & 5 & 6 & 7 & \\
\hline \multirow[t]{3}{*}{ Monday } & $\mathrm{cm} / \mathrm{second}$ & 17 & 17 & 19 & 22 & 28 & 32 & 37 & 45 \\
\hline & Grade $\left(^{\circ}\right)$ & 5 & 10 & 15 & 15 & 15 & 15 & 18 & 18 \\
\hline & Minutes & 15 & 15 & 30 & 30 & 30 & 30 & 30 & 30 \\
\hline \multirow[t]{3}{*}{ Tuesday } & $\mathrm{cm} / \mathrm{second}$ & 17 & 17 & 19 & 22 & 28 & 32 & 37 & 45 \\
\hline & Grade $\left(^{\circ}\right)$ & 5 & 13 & 15 & 15 & 15 & 15 & 18 & 18 \\
\hline & Minutes & 15 & 15 & 30 & 30 & 30 & 30 & 30 & 30 \\
\hline \multirow[t]{3}{*}{ Wednesday } & $\mathrm{cm} / \mathrm{second}$ & 17 & 19 & 19 & 22 & 28 & 32 & 37 & 45 \\
\hline & Grade $\left(^{\circ}\right)$ & 8 & 13 & 15 & 15 & 15 & 15 & 18 & 18 \\
\hline & Minutes & 15 & 15 & 30 & 30 & 30 & 30 & 30 & 30 \\
\hline \multirow[t]{3}{*}{ Thursday } & $\mathrm{cm} / \mathrm{second}$ & 17 & 19 & 19 & 22 & 28 & 32 & 37 & 45 \\
\hline & Grade $\left(^{\circ}\right)$ & 8 & 15 & 15 & 15 & 15 & 15 & 18 & 18 \\
\hline & Minutes & 15 & 15 & 30 & 30 & 30 & 30 & 30 & 30 \\
\hline \multirow[t]{3}{*}{ Friday } & $\mathrm{cm} / \mathrm{second}$ & 17 & 19 & 22 & 28 & 32 & 37 & 45 & 45 \\
\hline & Grade $\left(^{\circ}\right)$ & 10 & 15 & 15 & 15 & 15 & 15 & 18 & 18 \\
\hline & Minutes & 15 & 30 & 30 & 30 & 30 & 30 & 30 & 30 \\
\hline
\end{tabular}


Table 2. Weekly variation in treadmill speed, inclination, and running time of strenuous exercise group

\begin{tabular}{|c|c|c|c|c|c|c|c|c|c|}
\hline \multirow[b]{2}{*}{ Days } & & \multicolumn{7}{|c|}{ Weeks } & \multirow[b]{2}{*}{$8-13$} \\
\hline & & 1 & 2 & 3 & 4 & 5 & 6 & 7 & \\
\hline \multirow[t]{3}{*}{ Monday } & $\mathrm{cm} /$ second & 17 & 17 & 19 & 22 & 28 & 32 & 37 & 45 \\
\hline & Grade $\left(^{\circ}\right)$ & 5 & 10 & 15 & 15 & 15 & 15 & 18 & 18 \\
\hline & Minutes & 15 & 15 & 60 & 60 & 60 & 60 & 60 & 60 \\
\hline \multirow[t]{3}{*}{ Tuesday } & $\mathrm{cm} /$ second & 17 & 17 & 19 & 22 & 28 & 32 & 37 & 45 \\
\hline & Grade $\left(^{\circ}\right)$ & 5 & 13 & 15 & 15 & 15 & 15 & 18 & 18 \\
\hline & Minutes & 15 & 15 & 60 & 60 & 60 & 60 & 60 & 60 \\
\hline \multirow[t]{3}{*}{ Wednesday } & $\mathrm{cm} /$ second & 17 & 19 & 19 & 22 & 28 & 32 & 37 & 45 \\
\hline & Grade $\left(^{\circ}\right)$ & 8 & 13 & 15 & 15 & 15 & 15 & 18 & 18 \\
\hline & Minutes & 15 & 15 & 60 & 60 & 60 & 60 & 60 & 60 \\
\hline \multirow[t]{3}{*}{ Thursday } & $\mathrm{cm} /$ second & 17 & 19 & 19 & 22 & 28 & 32 & 37 & 45 \\
\hline & Grade $\left(^{\circ}\right)$ & 8 & 15 & 15 & 15 & 15 & 15 & 18 & 18 \\
\hline & Minutes & 15 & 15 & 60 & 60 & 60 & 60 & 60 & 60 \\
\hline \multirow[t]{3}{*}{ Friday } & $\mathrm{cm} /$ second & 17 & 19 & 22 & 28 & 32 & 37 & 45 & 45 \\
\hline & Grade $\left(^{\circ}\right)$ & 10 & 15 & 15 & 15 & 15 & 15 & 18 & 18 \\
\hline & Minutes & 15 & 45 & 60 & 60 & 60 & 60 & 60 & 60 \\
\hline
\end{tabular}

\section{Trace element determination}

Trace elements were analyzed essentially as previously reported (15-17). The levels of $\mathrm{Mn}, \mathrm{Co}$, and $\mathrm{Cr}$ in the frontal lobe, temporal lobe, brain stem, liver, and spleen were determined by a Perkin-Elmer Zeeman Z/3030 atomic absorption spectrophotometer equipped with a HGA-600 graphite furnace and an AS-60 auto-sampler. The spectral light sources were $\mathrm{Cr}, \mathrm{Mn}$, and $\mathrm{Co}$ hollow-cathode lamps. Results were calculated as $\mu \mathrm{g} \mathrm{Mn}, \mathrm{Co}$, or $\mathrm{Cr}$ per gram wet weight of tissues.

\section{Statistical analysis}

SPSS for Windows version 13.0 (SPSS Inc.) was used to analyze statistical data. Data normality was analyzed by the Shapiro-Wilk normality test. Because not all of the variables followed a normal distribution, the Kruskal-Wallis variance analyses were done among the groups, and then Mann-Whitney $U$ tests were used to compare variables between two groups. Spearman's correlation was also used to correlate variables, and $p$ values $<0.05$ were considered to be statistically significant.

\section{Results}

Initial body weights of rats in control, moderate and strenuous exercise groups and their alterations at the end of training protocol were shown in the Table 3 . Increase in body weight at the end of training was found to be significant only in moderate exercise group when compared to initial values.

Levels of trace element in the liver, spleen, and brain tissue of rats in the control, moderate and strenuous exercise
Table 3. Initial body weights of rats in control, moderate and strenuous exercise groups and their alterations at the end of training (mean $\pm S D$, grams)

\begin{tabular}{|lcc|}
\hline & Initial & $\begin{array}{c}\text { At the end } \\
\text { of training }\end{array}$ \\
\hline Control $(n=8)$ & $155.00 \pm 5.70$ & $232.80 \pm 20.59$ \\
Moderate Exercise $(n=7)$ & $164.00 \pm 4.11$ & $295.75 \pm 16.71$ * \\
Strenuous Exercise $(n=6)$ & $160.13 \pm 7.88$ & $269.38 \pm 15,49$ \\
\hline${ }^{*} p<0.005$ & & \\
\hline
\end{tabular}

groups are shown in Table 4 and Table 5. Statistical evaluations ( $p$ values) were also indicated in the tables. In the moderate exercise group, the level of Co significantly decreased in the brain stem, liver and spleen when compared to that of the control group, whereas the level of $\mathrm{Mn}$ was not significantly different from the controls except for a decrease in the spleen. The level of $\mathrm{Cr}$ in rats in the moderate exercise group was not significantly changed in the brain areas or in the spleen but was significantly higher in the liver compared to rats in the control group.

In the strenuous exercise group, the level of Co was significantly lower in the frontal lobe and the spleen than that of rats in the control group, whereas the level of $\mathrm{Mn}$ was significantly lower only in the brain stem Levels of $\mathrm{Cr}$ in the strenuous exercise group as compared to the control group were significantly higher in the liver but there were no significant differences in $\mathrm{Cr}$ levels in the spleen or in the frontal or temporal lobes. 
Table 4. Trace element levels of brain tissues in control, moderate and strenuous exercise groups. Values indicate $\mu$ g Mn, $\mathrm{Co}$, or $\mathrm{Cr}$ per gram of tissue (wet weight) and are represented by means \pm SD

\begin{tabular}{|c|c|c|c|c|c|c|c|}
\hline & & $\begin{array}{c}\text { Control } \\
(n=8)\end{array}$ & $\begin{array}{c}\text { Moderate exercise } \\
(\mathrm{n}=7)\end{array}$ & $p$ & $\begin{array}{l}\text { Strenuous exercise } \\
(n=6)\end{array}$ & $p$ & $\mathrm{p}^{\mathrm{a}}$ \\
\hline \multirow[t]{3}{*}{ Frontal lobe } & $\mathrm{Mn}$ & $1.81 \pm 1.53$ & $1.54 \pm 1.14$ & 0.888 & $0.57 \pm 0.47$ & 0.113 & 0.043 \\
\hline & Co & $4.21 \pm 3.43$ & $3.18 \pm 2.28$ & 0.724 & $0.24 \pm 0.09$ & 0.004 & 0.001 \\
\hline & $\mathrm{Cr}$ & $0.60 \pm 0.26$ & $1.28 \pm 0.78$ & 0.055 & $0.43 \pm 0.12$ & 0.304 & 0.073 \\
\hline \multirow[t]{3}{*}{ Temporal lobe } & $\mathrm{Mn}$ & $3.59 \pm 3.49$ & $0.44 \pm 0.24$ & 0.099 & $0.88 \pm 0.60$ & 0.254 & 0.310 \\
\hline & Co & $2.95 \pm 1.73$ & $2.31 \pm 0.69$ & 0.662 & $3.76 \pm 2.66$ & 0.905 & 0.497 \\
\hline & $\mathrm{Cr}$ & $0.60 \pm 0.41$ & $0.72 \pm 0.70$ & 0.963 & $1.45 \pm 0.87$ & 0.218 & 0.267 \\
\hline \multirow[t]{3}{*}{ Brain stem } & $\mathrm{Mn}$ & $1.38 \pm 0.46$ & $1.37 \pm 1.10$ & 0.491 & $0.33 \pm 0.14$ & 0.001 & 0.001 \\
\hline & Co & $2.44 \pm 1.78$ & $0.30 \pm 0.14$ & 0.009 & not detected & - & - \\
\hline & $\mathrm{Cr}$ & $0.55 \pm 0.48$ & $1.19 \pm 0.93$ & 0.230 & not detected & - & - \\
\hline
\end{tabular}

Table 5. Trace element levels of liver and spleen tissues in control, moderate and strenuous exercise groups. Values indicate $\mu \mathrm{g} \mathrm{Mn,} \mathrm{Co,} \mathrm{or} \mathrm{Cr}$ per gram of tissue (wet weight) and are represented by means $\pm \mathrm{SD}$

\begin{tabular}{|lccccccc|}
\hline & $\begin{array}{c}\text { Control } \\
(\mathbf{n}=\mathbf{8})\end{array}$ & $\begin{array}{c}\text { Moderate exercise } \\
(\mathbf{n}=\mathbf{7})\end{array}$ & $\mathbf{p}$ & $\begin{array}{c}\text { Strenuous exercise } \\
(\mathbf{n}=\mathbf{6})\end{array}$ & $\mathbf{p}$ & $\mathbf{p}^{\mathrm{a}}$ \\
\hline Liver & $\mathrm{Mn}$ & $2.15 \pm 0.57$ & $2.86 \pm 0.93$ & 0.068 & $2.42 \pm 0.50$ & 0.315 & 0.281 \\
& $\mathrm{Co}$ & $1.05 \pm 0.86$ & $0.21 \pm 0.18$ & 0.003 & $0.53 \pm 0.19$ & 0.315 & 0.009 \\
& $\mathrm{Cr}$ & $0.35 \pm 0.09$ & $0.92 \pm 0.38$ & 0.004 & $1.02 \pm 0.49$ & 0.001 & 0.694 \\
& $\mathrm{Mn}$ & $0.56 \pm 0.24$ & $0.22 \pm 0.24$ & 0.006 & $0.26 \pm 0.23$ & 0.073 & 0.852 \\
& $\mathrm{Co}$ & $1.13 \pm 0.83$ & $0.22 \pm 0.22$ & 0.019 & $0.51 \pm 0.50$ & 0.042 & 0.234 \\
\hline p: statistical significance and difference from control, p: statistical significance and difference from moderate exercise & & & \\
\hline
\end{tabular}

Neither Co nor $\mathrm{Cr}$ was detected in the brain stem in strenuous exercise group. When the strenuous exercise group was compared to moderate exercise group, the only statistically significant changes were a decrease in the levels of Co and $\mathrm{Mn}$ in the frontal lobe, a decrease in the level of $\mathrm{Mn}$ in the brain stem, and an increase in the level of $\mathrm{Co}$ in the liver. There were not any correlations among the variables in this study.

\section{Discussion}

In human subjects, investigation of trace element metabolism in non accessible tissues is virtually impossible because of inability of taking the tissue samples. To simulate these events, animal models, especially rat models, are frequently used to evaluate the identical events of human.

There are numerous studies showing evidence that many parts of the body are influenced by running exercise and enzymatic processes in which all the trace elements investigated in brain, liver and spleen have important functions are active during the exercise conditions used. There is no direct knowledge about the trace element changes in brain areas, liver and spleen during running exercise.
A previous study measuring Co levels in the brain found that the element was present in only six brain regions (the olfactory bulb, pons and medulla, inferior colliculus, diencephalon, hippocampus, and cerebellum) and not detected in two regions (telencephalon and superior colliculus); the concentration of $\mathrm{Co}_{\mathrm{O}}$ in these six regions was very low and showed few associations to these regions (18). Other work has shown that the liver and the spleen are the primary sites for the deposition of Co (19). In this study, we found that in the strenuous exercise group as compared to the control group, Co was depleted in the brain stem and frontal lobe. It is known that Co functions as a regulatory agent of the sympathetic nervous system and limits arterial blood pressure (20). Regarding this we can suggest that the depletion we observed might reflect the mobilization of Co among the brain areas to regulate sympathetic nervous system function during exercise. Moreover Co levels were also found to be decreased in liver and spleen in moderate and strenuous groups as compared to control group. Co is most probably excreted in the urine after exercise.

$\mathrm{Cr}$ is also metabolically important, and is involved in a large number of enzymatic processes. One crucial role concerns its ability to increase the number of insulin receptors, and to 
increase carbohydrate metabolism by acting as a potential cofactor for the glucose tolerance factor, which potentiates insulin activity. $\mathrm{Cr}$ and/or glucose tolerance factor may also be involved in lipid metabolism via a connection to insulin, which is involved in both lipid and carbohydrate metabolism. In response to the consumption of refined carbohydrates, there is a rapid rise in blood sugar leading to elevations in insulin that cause a mobilization of $\mathrm{Cr}$. Once mobilized, $\mathrm{Cr}$ is not $\mathrm{Cr}$ is not reabsorbed but lost via the urine leading to decreased $\mathrm{Cr}$ stores (21). Other evidence suggests that $\mathrm{Cr}$ may also play some role in increasing the concentration of high-density lipoprotein, and may contribute to gene expression and influence protein metabolism (20).

The metabolism of $\mathrm{Cr}$ is altered during physical stress, but surprisingly, variations in $\mathrm{Cr}$ levels during sports activities have not been extensively studied (22). Endurance activity may promote the depletion of $\mathrm{Cr}$ status and enhance the urinary excretion of $\mathrm{Cr}$ (23). The reason could be the complexing of $\mathrm{Cr}$ with the lactate that is produced by endurance-based exercise. In our study, rats in the strenuous exercise group had decreased levels of $\mathrm{Cr}$ in the brain stem, and this depletion may also be related to lactate-based $\mathrm{Cr}$ excretion. In contrast, our data from the moderate exercise group did not show any significant changes in $\mathrm{Cr}$ levels in the brain stem, suggesting that $\mathrm{Cr}$ was preserved during moderate exercise. Although we saw notable changes in $\mathrm{Cr}$ only in the brain stem in the strenuous exercise group, both our data and that of a previous study show that $\mathrm{Cr}$ is normally present at low concentrations not only in the brain stem, but also in the frontal and temporal lobes, and that there are no apparent associations among these regions (18). Similarly, another study found that $\mathrm{Cr}$ levels were distributed almost evenly among the brain frontal lobe and the cerebellum (19).

The physiological function of $\mathrm{Mn}$ is perhaps the least studied among these three trace elements. One role that is known is as a cofactor for superoxide dismutase, an enzyme that has antioxidant functions. With respect to exercise stress and antioxidant status, one study has shown that a decrease in levels of $\mathrm{Mn}$ superoxide dismutase after nutritional intervention with a yeast cell preparation that is rich in antioxidants and trace elements and minerals can be interpreted as a sign of reduced free radical stress (20). In this context, it is notable that after intense physical exercise, Mn levels in saliva decreased (24). Metalloenzymes (other than superoxide dismutase) for which $\mathrm{Mn}$ is a cofactor include arginase, pyruvate carboxylase and glutamine synthetase (25). Glutamine, which is also involved in antioxidation, in that it is one of the three amino acid constituents of glutathione, a cellular antioxidant, and it is notable that glutamine is also the most abundant amino acid in the organism, especially in muscles (26-28). Despite the relative paucity of information on the detailed biochemistry and physiology of $\mathrm{Mn}$, it has been demonstrated to act on the nervous system as a calcium antagonist, and also to have a role in skeletal growth, in the synthesis of nucleic acids, proteins and hemoglobin, and in the metabolism of lipids and carbohydrates. It acts on the nervous system as a calcium antagonist and is several times as efficient as $\mathrm{Mg}+2$ in inhibiting the release of neuromediators into synaptic space, probably because of competition with $\mathrm{Ca}+2$ at the level of calcium channels (20). Several works have examined the distribution of $\mathrm{Mn}$ in organs, and have shown that in the brain, $\mathrm{Mn}$ is not restricted to certain regions but is uniformly distributed across eight brain regions (olfactory bulb, telencephalon, superior colliculus, pons and medulla, inferior colliculus, diencephalon, hippocampus and cerebellum) (18). Other studies demonstrated that the liver is a major site of deposition for $\mathrm{Mn}$ and $\mathrm{Mn}$ is also found in the pancreas so it may be useful to examine pancreatic $\mathrm{Mn}$ levels after exercise in future studies $(19,29-33)$.

We have demonstrated that in a rat model, single bout of moderate and strenuous running exercise acutely affects trace element metabolism in the brain, liver and spleen. $\mathrm{Cr}$ levels in liver of rats increased in parallel to the time course of running. A notable finding was that after strenuous exercise, levels of Co decreased in the spleen and dramatically decreased in the brain stem in parallel to the time course of running exercise, suggesting that perhaps Co was being redistributed to other organ systems and excreted most probably by urinary excretion. Therefore, it may be helpful for athletes to take supplemental Co in order to prevent a possible Co deficiency that might result from strenuous exercise.

Ethics Committee Approval: Ethics committee approval was received from the Inönü University Ethics Committee for Experimental Animals for this study.

\section{Informed Consent: N/A.}

Peer-review: Externally peer-reviewed.

Author contributions: Concept - K.E., Y.K.; Design - K.E., Y.K.; Supervision - K.E., Y.K., M.H.E.; Resource - K.E., H.I., H.D.; Materials - K.E., H.i., H.D.; Data Collection\&/or Processing - K.E., H.I., H.D.; Analysis\&/ or Interpretation - K.E., H.I., Y.K., M.H.E.; Literature Search - K.E.; Writing - K.E.; Critical Reviews - K.E., Y.K., M.H.E.

Conflict of Interest: No conflict of interest was declared by the authors.

Financial Disclosure: No financial disclosure was declared by the authors.

\section{References}

1. Kozma M, Ferke A. Trace element localization and changes in zinc and copper concentrations during postnatal development of the rat CNS. Acta Histochem 1979;65:219-27. [CrossRef]

2. Rath FW, Grahl R, Felicetti D. The histochemical behaviour of zinc-activated tartrate-resistant phosphatase (ZnTP) in early stages of experimental tumors in the rat trigeminal nerve. Exp Pathol (Jena) 1980;18:25-30. [CrossRef]

3. Usdin TB, Creese I, Snyder SH. Regulation by cations of [3H] spiroperidol binding associated with dopamine receptors of rat brain. J Neurochem 1980;34:669-76. [CrossRef]

4. Leong SF, Lai JC, Lim L, Clark JB. Energy-metabolizing enzymes in brain regions of adult and aging rats. J Neurochem 1981;37:1548-56. [CrossRef]

5. Lai JC, Leung TK, Lim L. Brain regional distribution of glutamic acid decarboxylase, choline acetyltransferase, and acetylcholinesterase in the rat:effects of chronic manganese chloride administration after two years. J Neurochem 1981;36:1443-8. [CrossRef]

6. Kemp K, Danscher G. Multi-element analysis of the rat hippocampus by proton induced X-ray emission spectroscopy (phos- 
phorus, sulphur, chlorine, potassium, calcium, iron, zinc, copper, lead, bromine, andrubidium). Histochemistry 1976;59:167-76. [CrossRef]

7. Rajan KS, Colburn RW, Davis JM. Distribution of metal ions in the subcellular fractions of several rat brain areas. Life Sci 1976;18:423-31. [CrossRef]

8. Chan AW, Minski MJ, Lai JC. An application of neutron activation analysis to small biological samples:simultaneous determination of thirty elements in rat brain regions. J Neurosci Methods 1983;7:317-28. [CrossRef]

9. Takahashi S, Takahashi I, Sato H, Kubota Y, Yoshida S, Muramatsu $Y$. Age-related changes in the concentrations of major and trace elements in the brain of rats and mice. Biol Trace Elem Res 2001;80:145-58. [CrossRef]

10. Anderson RA. Recent advances in the clinical and biochemical effects of chromium deficiency. In:Prasad AS, ed. Essential and Toxic Trace Elements in Human Health and Disease:An Update. New York:Wiley Liss;1993:221-34.

11. Anderson RA, Polansky MM, Bryden NA, Roginski EE, Patterson $K Y$, Reamer DC. Effect of exercise (running) on serum glucose, insulin, glucagon, and chromium excretion. Diabetes 1992;31:212-6. [CrossRef]

12. Vallerand AL, Cuerrier JP, Shapcott D, Vallerand RJ, Gardiner PF. Influence of exercise training on tissue chromium concentrations in the rat. Am J Clin Nutr 1984;39:402-9.

13. Kobla HV, Volpe SV. Chromium, exercise, and body composition. Crit Rev Food Sci Nutr 2000;40:291-308. [CrossRef]

14. Rico H, Gervas JJ, Hernandez ER, Seco C, Villa LF, Revilla M, et al. Effects of alprazolam supplementation on vertebral and femoral bone mass in rats on strenuous treadmill training exercise. Calcif Tissue Int 1999;65:139-42. [CrossRef]

15. Evenson MA, Anderson CT Jr. Ultramicro analysis for copper, cadmium, and zinc in human liver tissue by use of atomic absorption spectrophotometry and the heated graphite tube atomizer. Clin Chem 1975;21:537-43.

16. Brys M, Nawrocka AD, Miekos E, Zydek C, Foksinski M, Barecki $A$, et al. Zinc and cadmium analysis in human prostate neoplasms. Biol Trace Elem Res 1997;59:145-52. [CrossRef]

17. Karakoc Y, Yurdakos E, Gulyasar T, Mengi M, Barutcu UB. Experimental stress-induced changes in trace element levels of various tissues in rats. J Trace Elem Med Biol 2003;161:55-60.

18. Paul MC, Parsons $\mathrm{CH}$, Calford MB, von Nagy-Felsobouki El. Multi-elemental analysis of brain tissue fom healthy Wistar rats using sector field inductively coupled plasma mass spectrometry. Spectrochim Acta Part B At Spectrosc 2004;59B:1485-90. [CrossRef]
19. Rahil-Khazen R, Bolann BJ, Myking A, Ulvik RJ. Multi-element analysis of trace element levels in human autopsy tissues by using inductively coupled atomic emission spectrometry technique (ICP-AES). J Trace Elem Med Biol 2002;16:15-25. [CrossRef]

20. Speich M, Pineau A, Ballereau F. Minerals, trace elements and related biological variables in athletes and during physical activity. Clin Chim Acta 2001;312:1-11. [CrossRef]

21. Anderson RA. Chromium and insulin resistance. Nutr Res Rev 2003;16:267-75. [CrossRef]

22. Lukaski HC. Magnesium, zinc, and chromium nutriture and physical activity. Am J Clin Nutr 2000;72:585S-593S.

23. Frentsos JA, Baer JT. Increased energy and nutrient intake during training and competitionimproves elite triathletes' endurance performance. Int J Sport Nutr 1997;7:61-71.

24. Chicharro JL, Serrano V, Urena R, Gutierrez AM, Carvajal A, Fernandez-Hernando $P$, et al. Trace elements and electrolytes in human resting mixed saliva after exercise. $\mathrm{Br} \mathrm{J}$ Sports Med 1999;33:204-7. [CrossRef]

25. Pohl AP, O'Halloran MW, Pannall PR. Biochemical and physiological changes in football players. Med J Aust 1981;1:467-70.

26. Brites FD, Evelson PA, Christiansen MG, Nicol MF, Basilico MJ, Wikinski RW, et al. Soccer players under regular training show oxidative stress but an improved plasma antioxidant status. Clin Sci (Lond) 1999;96:381-5. [CrossRef]

27. Clarkson PM, Thompson HS. Antioxidants:what role do they play in physical activity and health? Am J Clin Nutr 2000;72(Suppl 2):637S-46S.

28. Pincemail J, Lecomte J, Castiau J, Collard E, Vasankari T, CheramyBien J, et al. Evaluation of autoantibodies against oxidized LDL and antioxidant status in top soccer and basketball players after 4 months of competition. Free Radic Biol Med 2000;28:559-65. [CrossRef]

29. Aalbers TG, Houtman JP, Makkink B. Trace-element concentrations in human autopsy tissue. Clin Chem 1987;33:2057-64.

30. Honda R, Nogawa K. Cadmium, zinc and copper relationships in kidney and liver of humans exposed to environmental cadmium. Arch Toxicol 1987;59:437-42. [CrossRef]

31. Lyon TD, Fell GS, Halls DJ, Clark J, McKenna F. Determination of nine inorganic elements in human autopsy tissue. J Trace Elem Electrolytes Health Dis 1989;3:109-18.

32. Carvalho ML, Brito J, Barreiros MA. Study of trace element concentrations in human tissues by EDXRF Spectrometry. X-Ray Spectrometry 1998;27:198-204. [CrossRef]

33. Llobet JM, Granero S, Schuhmacher M, Corbella J, Domingo JL. Biological monitoring of environmental pollution and human exposure to metals in Tarragona, Spain II Levels in autopsy tissues. Trace Elements Electrolytes 1998;15:44-9. 